\title{
EVALUATION OF MICROPHYSICAL PARAMETERIZATIONS OF THE WRF MODEL IN A TROPICAL REGION
}

\author{
Noéle Bissoli Perini de Souza ${ }^{a}$, Erick Giovani Sperandio Nascimento ${ }^{b}$, Davidson \\ Martins Moreira ${ }^{b}$ \\ ${ }^{a}$ Federal University of Espirito Santo-UFES, ES, Brazil \\ ${ }^{b}$ Manufacturing and Technology Integrated Campus - SENAI CIMATEC, BA, Brazil
}

\begin{abstract}
The performance evaluation of the Weather Research and Forecasting (WRF) model was carried out using eight microphysics schemes in order to identify the best parameters for the most and least rainy periods. The modeling results were compared with the observational data from a tower located in the municipality of Esplanada, in the state of Bahia, with anemometers at heights of 80, 100, 120 and 150 $\mathrm{m}$. In general, it was found that all tested schemes can be used in tropical regions, however, it can be concluded that Eta and Kessler showed better performances for the more and less rainy period, respectively, in addition to overestimating the speed.
\end{abstract}

Keywords: microphysics; WRF; tropical region.

\section{AVALIAÇÃO DAS PARAMETRIZAÇÕES DE MICROFÍSICA DO MODELO WRF EM UMA REGIÃO TROPICAL}

Resumo: A avaliação do desempenho do modelo Weather Research and Forecasting (WRF) foi realizada utilizando oito esquemas de microfísica a fim de identificar as melhores parametrizações para os períodos mais e menos chuvoso. Os resultados da modelagem foram comparados com os dados observacionais provenientes de uma torre localizada no município de Esplanada, no estado baiano, com anemômetros em alturas de $80,100,120$ e $150 \mathrm{~m}$. No geral, constatou-se que todos os esquemas testados podem ser utilizados em regiões tropicais, porém, pode-se concluir que Eta e Kessler apresentaram melhores desempenhos para o período mais e menos chuvoso, respectivamente, além de superestimar a velocidade.

Palavras-chave: microfísica; WRF; região tropical. 


\section{INTRODUCTION}

The generation of electricity through winds can serve as a complementary source to the hydroelectric modality in regions affected by droughts, as in the case of Northeast Brazil (NEB) [1]. The Northeast region stands out for being the region with the largest generation of wind energy in Brazil, corresponding to $84.7 \%$ of all national wind production [2]. Among the northeastern states is the state of Bahia, which, located in the tropics, stands out as the second largest producer of wind energy in Brazil and the state that receives the most wind projects. Weather forecasting and simulation in the tropics are challenging, as the tropical climate can change rapidly with convection and sea breeze and is dominated by local, meso and macro scale effects. Winds in the tropics are generally light and variable. In addition, the surface and upper air observations required for numerical weather forecasting models are also scarce [3].

The WRF (Weather Research and Forecasting) model [4], which is a model of numerical weather forecasting, is widely used in air pollution research and evaluation of wind and solar energy production. Their physical parameterizations can be divided into different categories, each containing several parameterizations available for modeling the planetary boundary layer, terrestrial surface, superficial layer, microphysics, cumulus and long wave and short wave radiation. Physical parameterizations are ways of describing physical processes using simplified equations in order to reduce the number of unknowns that govern the atmosphere. Thus, part of the efforts of scientific studies is focused on defining better physical parameters, comparing with data measured in different parts of the world, for the most diverse applications [5-9]. It should be noted that the studies of these schemes are not trivial and require several simulations, and these studies focused on evaluating the model's performance in tropical regions. The simulation of weather forecasting in tropical regions is challenging, as these regions have an intense convective characteristic, changing the state of the atmosphere quickly, in addition to being influenced by sea breezes and local and mesoscale movements $[3,10]$.

In particular, the parameterization of microphysics solves the explicit processes of water vapor, rain, snow, ice, clouds and hail, at the end of each time step, as an adjustment process to ensure that the final saturation balance is more accurate to update temperature and humidity. Several microphysics parameterization schemes have been used in wind energy research, such as, WSM6 [11-13], Thompson [14], WSM3 [15], WDM6 [16-18], WSM5 [19], Lin [20].

Therefore, this article aims to evaluate the performance of eight microphysics parameterization schemes - Eta, Kessler, Lin, Thompson, WRF Double-Moment 6class (WDM6), WRF Single-Moment 3-class (WSM3), WRF Single-Moment 5-class (WSM5), WRF Single-Moment 6-class (WSM6) - using the WRF model in order to identify the best parameterization of microphysics for periods of more and less rain, for use in studies of wind potential in the state of Bahia. For this purpose, the simulations will be carried out and compared with wind speed data collected at times compatible with that of the wind generators. Unlike most studies that use surface data $(10 \mathrm{~m})$ to validate the results, this study will use data from anemometric tower up to $150 \mathrm{~m}$, which are the height of wind towers today. This tower is located in the municipality of Esplanada in the state of Bahia, which is a large tropical region. 


\section{METHODOLOGY}

\subsection{Study Area}

The predominant climate in the state of Bahia is tropical, with average high and maximum annual temperatures above $30^{\circ} \mathrm{C}$. In the coastal strip, the humidity is higher and the annual accumulated precipitation exceeds $1600 \mathrm{~mm}$ in some regions [21]. The municipality of Esplanada is located in the micro region of the northern coast of Bahia with an altitude of $158 \mathrm{~m}$. Its anemometric tower is $40 \mathrm{~km}$ from the sea, with a latitude of $11^{\circ} 50^{\prime} 55.22953$ "S and a longitude of $37^{\circ} 55^{\prime} 44.31164 " \mathrm{O}$. Analyzing the climatological normal (Figure 1) available for the Alagoinhas station (closest to the Esplanada), it appears that the months of January, February and September appear as less rainy months, while May and June are the rainiest months for this region.

Figure 1. Comparative Accumulated Precipitation ( $\mathrm{mm}$ ) at Alagoinhas Station (83249).

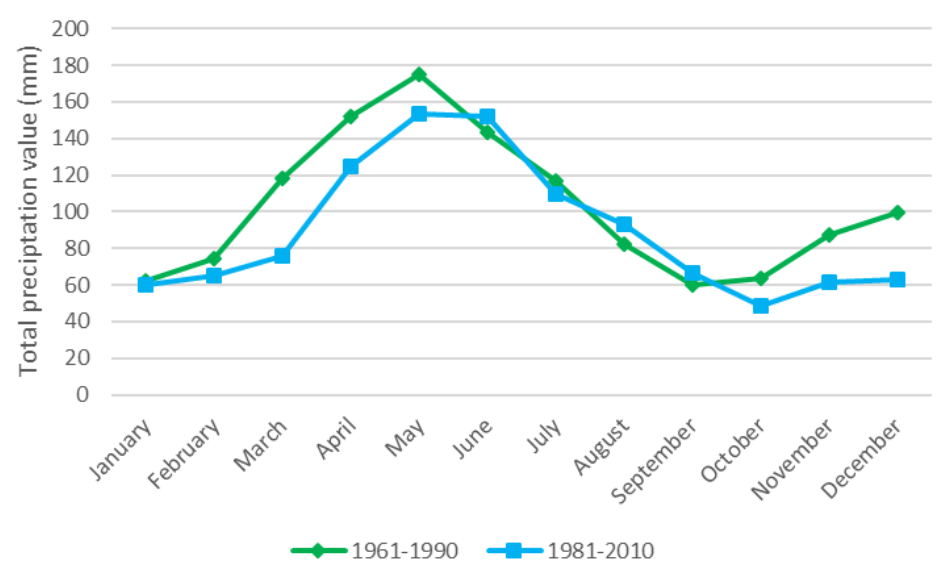

Source: INMET (2020).

\subsection{Model Configuration}

The study was carried out using the meteorological model WRF version 3.9. The WRF model was configured with two nested domains with grid resolutions of 9 and 3 $\mathrm{km}$, respectively. Inside the second domain, which covers the entire state of Bahia, four domains were designed with $1 \mathrm{~km}$ grid resolutions, centered on the four anemometric towers: Mucugê (Domain 3), Esplanade (Domain 4), Mucuri (Domain 5) and Casa Nova (Domain 6). This work will show only the results of Esplanada. Figure 2 shows the location and distribution of domains in the WRF model. The domains were designed with horizontal dimensions of $223 \times 223$ and $420 \times 420$ grid cells for domains 1 and 2, respectively, and 60x60 grid cells for domains 3 to 6 . For the initialization of the WRF, data from the National Centers for Environmental Prediction (NCEP) Final Analysis (FNL) with a spatial resolution of $0.25^{\circ}$ were used [23]. Land use and occupation were provided by the United States Geological Survey (USGS) with a resolution of 2' for the largest domain and 30" for the others, which are the data that are available in the standard installation of the WRF model. 
Figure 2. Location and distribution of anemometric towers and domains in the WRF model.

Generated with the help of Google Earth.
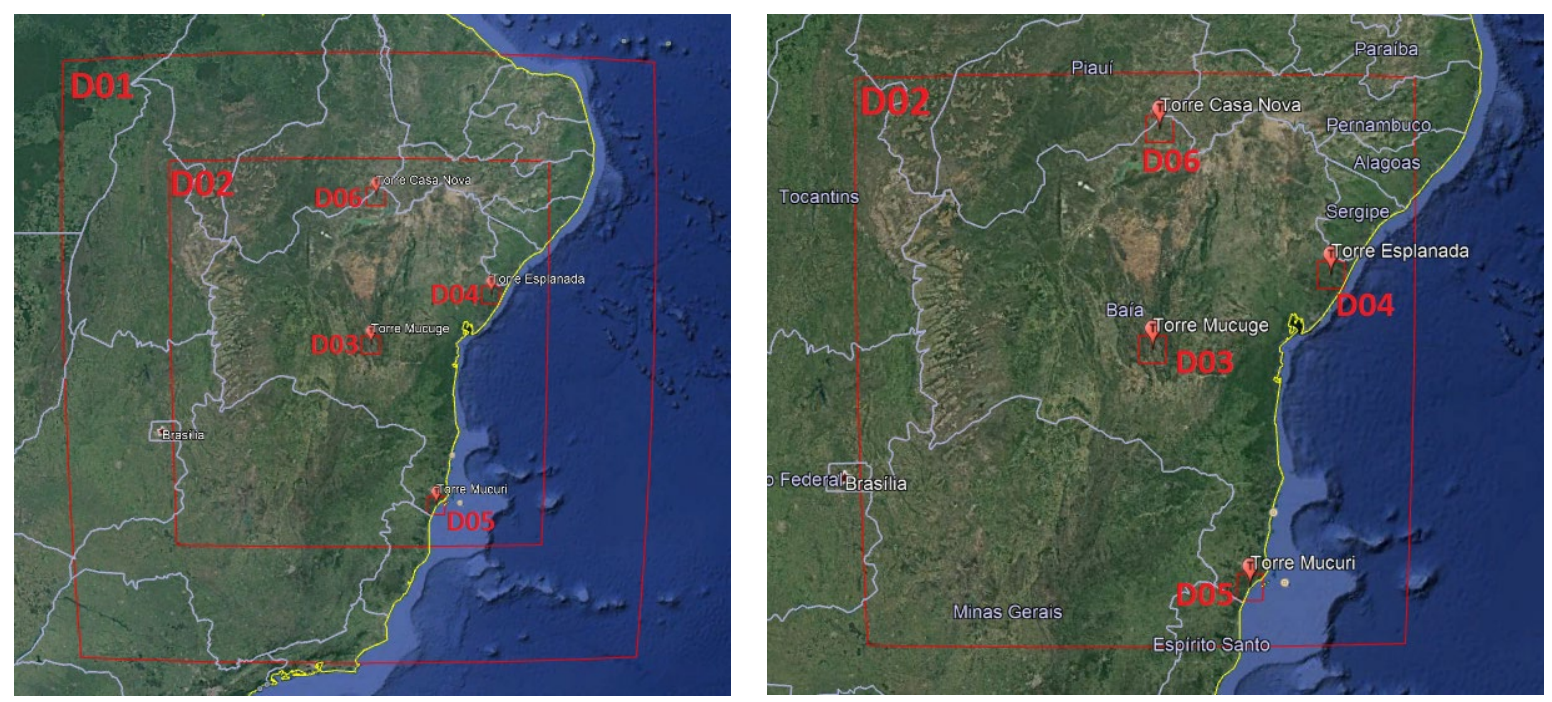

The simulations were carried out monthly for the months of January, February, May, June and September, including $24 \mathrm{~h}$ spin-up to obtain realistic initial conditions, that is, the simulation for each month was started from 00:00 UTC on last day of the previous month. Regarding the physical parameterization of the model, Kitagawa et al. [24] highlights the scheme Mellor-Yamada-Janjić - MYJ [25] as the best planetary boundary layer scheme (PBL) for the Metropolitan Region of Salvador (MRS) and, consequently, Eta similarity as the best superficial layer scheme (LS). Since Salvador is the capital of Bahia, and since there are no other studies on this subject for the state, the MYJ and Eta schemes were initially used in this work to parameterize the planetary boundary layer and the superficial layer, respectively. The other physical options adopted were left unchanged for all simulations, and are shown in Table 1, as well as the tested microphysics options.

Table 1. Details of the simulation specifying the physical options

\begin{tabular}{|c|c|c|c|c|c|c|c|c|}
\hline Simulation & 1 & 2 & 3 & 4 & 5 & 6 & 7 & 8 \\
\hline Microphysics & Eta & Kessler & Lin & Thompson & WDM6 & WSM3 & WSM5 & WSM6 \\
\hline$P B L$ & \multicolumn{8}{|c|}{ MYJ scheme } \\
\hline Surface layer & \multicolumn{8}{|c|}{ Eta scheme } \\
\hline Cumulus & \multicolumn{8}{|c|}{ Betts-Miller-Janjić scheme } \\
\hline Shortwave radiation & \multicolumn{8}{|c|}{ RRTMG scheme } \\
\hline Longwave radiation & \multicolumn{8}{|c|}{ RRTMG scheme } \\
\hline Land surface model & \multicolumn{8}{|c|}{ Noah land surface scheme } \\
\hline
\end{tabular}

\subsection{Statistical metrics}

To compare the model simulations, meteorological observations of wind speed, at 150,120, 100 and $80 \mathrm{~m}$ in height, from the Esplanade Tower were used. The performance of the model was assessed using the statistical metrics of the Mean Bias (MB), Root Mean Squared Error (RMSE) e concordance index (IOA) [3,11,12,26-28]. 


\section{RESULTS AND DISCUSSION}

Tables 2 and 3 show the statistical metrics for periods of more and less rain, respectively, for wind speed, separated monthly, for heights of 150,120, 100 and 80 $\mathrm{m}$. Values in bold represent better results, paying attention to the fact that lower values for MB and RMSE, and higher values for IOA, represent better accuracy of the model.

Table 2. Results of statistical metrics when comparing simulated and observed wind speed data for the rainiest period.

\begin{tabular}{|c|c|c|c|c|c|c|c|c|c|c|}
\hline Alt. & $\begin{array}{l}\text { Mo } \\
\text { nth }\end{array}$ & $\begin{array}{c}\text { Statisti } \\
\text { cal }\end{array}$ & Eta & $\begin{array}{c}\text { Kessl } \\
\text { er }\end{array}$ & Lin & Thompson & WDM6 & WSM3 & WSM5 & WSM6 \\
\hline \multirow{6}{*}{ ถ્亏 } & \multirow{3}{*}{$\sum^{\vec{\pi}}$} & MB & 0,123 & 0,203 & 0,331 & 0,351 & 0,583 & 0,494 & 0,383 & 0,460 \\
\hline & & RMSE & 1,822 & 1,901 & 1,788 & 1,758 & 1,793 & 1,772 & 1,750 & 1,742 \\
\hline & & IOA & 0,645 & 0,605 & 0,642 & 0,661 & 0,655 & 0,635 & 0,649 & 0,661 \\
\hline & \multirow{3}{*}{$\Xi$} & MB & 0,018 & 0,233 & $-0,080$ & 0,166 & 0,890 & 0,311 & 0,459 & 0,448 \\
\hline & & RMSE & 2,081 & 2,192 & 2,327 & 2,143 & 2,261 & 2,071 & 2,150 & 2,114 \\
\hline & & IOA & 0,732 & 0,703 & 0,664 & 0,715 & 0,696 & 0,720 & 0,701 & 0,714 \\
\hline \multirow{6}{*}{ ‡్ } & \multirow{4}{*}{$\sum^{\lambda}$} & MB & 0,181 & 0,277 & 0,441 & 0,449 & 0,689 & 0,591 & 0,480 & 0,550 \\
\hline & & RMSE & 1,792 & 1,915 & 1,785 & 1,779 & 1,823 & 1,780 & 1,749 & 1,764 \\
\hline & & IOA & 0,646 & 0,594 & 0,646 & 0,653 & 0,647 & 0,637 & 0,656 & 0,661 \\
\hline & & MB & 0,110 & 0,272 & $-0,019$ & 0,222 & 0,951 & 0,382 & 0,509 & 0,502 \\
\hline & \multirow[t]{2}{*}{$\Xi$} & RMSE & 2,071 & 2,147 & 2,299 & 2,092 & 2,263 & 2,036 & 2,140 & 2,103 \\
\hline & & IOA & 0,714 & 0,690 & 0,646 & 0,705 & 0,679 & 0,710 & 0,686 & 0,696 \\
\hline \multirow{6}{*}{ క్ } & \multirow{3}{*}{$\stackrel{\vec{\pi}}{\Sigma}$} & MB & 0,206 & 0,306 & 0,495 & 0,499 & 0,740 & 0,633 & 0,528 & 0,591 \\
\hline & & RMSE & 1,780 & 1,934 & 1,793 & 1,780 & 1,846 & 1,788 & 1,752 & 1,780 \\
\hline & & IOA & 0,647 & 0,587 & 0,650 & 0,656 & 0,646 & 0,640 & 0,663 & 0,663 \\
\hline & \multirow{3}{*}{$\Xi$} & MB & 0,178 & 0,326 & 0,059 & 0,289 & 1,008 & 0,461 & 0,560 & 0,528 \\
\hline & & RMSE & 2,034 & 2,132 & 2,267 & 2,056 & 2,279 & 2,017 & 2,133 & 2,074 \\
\hline & & IOA & 0,704 & 0,675 & 0,635 & 0,695 & 0,663 & 0,701 & 0,676 & 0,685 \\
\hline \multirow{6}{*}{ క్ } & \multirow{3}{*}{$\sum^{\mathrm{I}}$} & MB & 0,116 & 0,200 & 0,436 & 0,421 & 0,664 & 0,544 & 0,434 & 0,503 \\
\hline & & RMSE & 1,719 & 1,876 & 1,764 & 1,738 & 1,822 & 1,766 & 1,722 & 1,740 \\
\hline & & IOA & 0,670 & 0,622 & 0,668 & 0,679 & 0,662 & 0,659 & 0,685 & 0,684 \\
\hline & \multirow{3}{*}{$\Xi$} & MB & 0,126 & 0,252 & $\mathbf{0 , 0 3 7}$ & 0,183 & 0,902 & 0,376 & 0,413 & 0,436 \\
\hline & & RMSE & 1,939 & 2,005 & 2,156 & 1,947 & 2,177 & 1,919 & 1,980 & 1,946 \\
\hline & & IOA & 0,713 & 0,685 & 0,645 & 0,699 & 0,674 & 0,709 & 0,694 & 0,705 \\
\hline
\end{tabular}

Table 3. Results of statistical metrics when comparing simulated and observed wind speed data for the least rainy season.

\begin{tabular}{|c|c|c|c|c|c|c|c|c|c|c|}
\hline Alt. & $\begin{array}{l}\text { Mo } \\
\text { nth }\end{array}$ & $\begin{array}{c}\text { Statisti } \\
\text { cal. }\end{array}$ & Eta & Kessler & Lin & Thompson & WDM6 & WSM3 & WSM5 & WSM6 \\
\hline \multirow{9}{*}{ ڤ్ี } & \multirow{3}{*}{ 胥 } & MB & 0,875 & 0,707 & 1,212 & 1,304 & 1,143 & 1,535 & 1,453 & 1,308 \\
\hline & & RMSE & 2,471 & 2,393 & 2,636 & 2,723 & 2,616 & 2,707 & 2,671 & 2,554 \\
\hline & & IOA & 0,624 & 0,615 & 0,597 & 0,584 & 0,612 & 0,605 & 0,617 & 0,630 \\
\hline & \multirow{3}{*}{ i } & MB & 0,079 & $-0,010$ & 0,259 & 0,445 & 0,422 & 0,398 & 0,383 & 0,366 \\
\hline & & RMSE & 1,522 & 1,732 & 1,575 & 1,592 & 1,702 & 1,599 & 1,630 & 1,682 \\
\hline & & IOA & 0,667 & 0,580 & 0,706 & 0,695 & 0,652 & 0,685 & 0,662 & 0,659 \\
\hline & \multirow{3}{*}{$\begin{array}{l}\text { वे } \\
\text { हn }\end{array}$} & MB & 0,010 & 0,193 & 0,189 & 0,288 & 0,814 & 0,432 & 0,448 & 0,469 \\
\hline & & RMSE & 2,055 & 2,147 & 1,965 & 2,027 & 2,044 & 1,985 & 2,048 & 2,016 \\
\hline & & IOA & 0,449 & 0,448 & 0,530 & 0,494 & 0,530 & 0,526 & 0,529 & 0,513 \\
\hline \multirow{6}{*}{$\underset{\Xi}{\Xi ્ \Xi ~}$} & \multirow{3}{*}{ Еี } & MB & 0,945 & 0,786 & 1,260 & 1,372 & 1,196 & 1,581 & 1,505 & 1,342 \\
\hline & & RMSE & 2,416 & 2,351 & 2,596 & 2,686 & 2,588 & 2,679 & 2,634 & 2,504 \\
\hline & & IOA & 0,626 & 0,616 & 0,596 & 0,584 & 0,611 & 0,606 & 0,623 & 0,631 \\
\hline & \multirow{3}{*}{8} & MB & 0,255 & 0,163 & 0,460 & 0,648 & 0,619 & 0,587 & 0,562 & 0,550 \\
\hline & & RMSE & 1,544 & 1,780 & 1,583 & 1,622 & 1,700 & 1,615 & 1,655 & 1,693 \\
\hline & & IOA & 0,675 & 0,600 & $\mathbf{0 , 7 2 0}$ & 0,708 & 0,678 & 0,700 & 0,679 & 0,680 \\
\hline
\end{tabular}




\begin{tabular}{|c|c|c|c|c|c|c|c|c|c|c|}
\hline \multirow{12}{*}{$\S$} & \multirow{3}{*}{ ঠे } & MB & 0,169 & 0,368 & 0,357 & 0,470 & 1,016 & 0,594 & 0,602 & 0,633 \\
\hline & & RMSE & 2,099 & 2,245 & 2,077 & 2,088 & 2,180 & 2,086 & 2,143 & 2,098 \\
\hline & & IOA & 0,465 & 0,452 & 0,518 & 0,500 & 0,515 & 0,524 & $\mathbf{0 , 5 2 7}$ & 0,512 \\
\hline & \multirow{3}{*}{ 点 } & MB & 0,931 & 0,776 & 1,199 & 1,304 & 1,121 & 1,524 & 1,456 & 1,274 \\
\hline & & RMSE & 2,346 & 2,282 & 2,508 & 2,605 & 2,517 & 2,605 & 2,555 & 2,419 \\
\hline & & IOA & 0,635 & 0,631 & 0,611 & 0,596 & 0,618 & 0,618 & 0,623 & 0,641 \\
\hline & \multirow{4}{*}{ Q0 } & $\mathrm{MB}$ & 0,351 & 0,245 & 0,576 & 0,756 & 0,736 & 0,692 & 0,662 & 0,645 \\
\hline & & RMSE & 1,604 & 1,839 & 1,614 & 1,661 & 1,717 & 1,660 & 1,699 & 1,720 \\
\hline & & IOA & 0,681 & 0,600 & 0,729 & 0,718 & 0,699 & 0,708 & 0,691 & 0,696 \\
\hline & & $\mathrm{MB}$ & 0,292 & 0,477 & 0,489 & 0,614 & 1,168 & 0,716 & 0,708 & 0,759 \\
\hline & \multirow{3}{*}{ ळे } & RMSE & 2,110 & 2,283 & 2,141 & 2,133 & 2,276 & 2,143 & 2,184 & 2,150 \\
\hline & & IOA & 0,497 & 0,486 & 0,526 & 0,511 & 0,521 & 0,542 & 0,546 & 0,529 \\
\hline \multirow{9}{*}{ 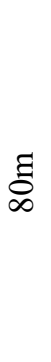 } & & $\mathrm{MB}$ & 0,729 & 0,545 & 0,953 & 1,044 & 0,934 & 1,230 & 1,199 & 1,013 \\
\hline & \multirow[t]{2}{*}{ ฮี } & RMSE & 2,146 & 2,137 & 2,299 & 2,373 & 2,354 & 2,364 & 2,358 & 2,221 \\
\hline & & IOA & 0,674 & 0,659 & 0,651 & 0,637 & 0,651 & 0,660 & 0,655 & 0,676 \\
\hline & \multirow{4}{*}{$\begin{array}{l}\text { ब0 } \\
\text { ex }\end{array}$} & $\mathrm{MB}$ & 0,317 & 0,202 & 0,562 & 0,732 & 0,724 & 0,652 & 0,618 & 0,606 \\
\hline & & RMSE & 1,608 & 1,812 & 1,605 & 1,637 & 1,685 & 1,632 & 1,669 & 1,689 \\
\hline & & IOA & 0,716 & 0,650 & 0,757 & 0,752 & 0,739 & 0,744 & 0,733 & 0,734 \\
\hline & & $\mathrm{MB}$ & 0,173 & 0,386 & 0,417 & 0,537 & 1,117 & 0,616 & 0,609 & 0,693 \\
\hline & \multirow{2}{*}{ 尺े } & RMSE & 2,158 & 2,272 & 2,220 & 2,184 & 2,294 & 2,187 & 2,246 & 2,171 \\
\hline & & IOA & 0,515 & 0,532 & 0,531 & 0,526 & 0,554 & 0,559 & 0,560 & 0,551 \\
\hline
\end{tabular}

From the analysis of these tables, it can be seen that, in general, all eight investigated microphysics parameters represent well the simulated behavior, that is, they can be used in tropical regions such as the Brazilian region of Bahia. The statistics, in general, did not show great differences between the simulated and observed values in each tested scheme. However, it can be seen that the Eta parameterization, in general, provides relative improvements in the simulations' performance for the rainiest period, in this case corresponding to the simulated May and June months. However, for the less rainy period (January, February and September), the Kessler microphysics parameterization scheme performed better compared to the others. Finally, it is observed that the simulations tend to slightly overestimate the wind speed (positive MB).

\section{CONCLUSION}

This work aimed to evaluate the performance of eight microphysical parameterization schemes using the WRF model, for the Esplanada region in the state of Bahia, in order to identify the best microphysical parameterization to be applied in the analysis of wind potential using numerical modeling. Thus, it can be concluded that all tested microphysics schemes can be used in tropical regions (study region), since the statistics, in general, did not show great differences between the simulated and observed values in each tested scheme. However, the parametrizations of Eta and Kessler microphysics, showed better performances for the forecast of wind speed, for the rainiest (May and June) and less rainy (January, February and September) periods, respectively.

In order to identify and select a better set of physical parameterizations for the Bahia region, future work will be carried out with the aim of testing the PLC schemes. Initially in this article, the MYJ scheme for PBL was used as the initial condition, identified as the best option for the Metropolitan Region of Salvador by Kitagawa et al. [24], located within the region of study of this work, however it does not cover the entire 
extension, which is the entire state of Bahia. Thus, it will be necessary to carry out new simulations in order to test the PBL schemes, to obtain better results.

\section{Acknowledgments}

The authors are grateful to the Supercomputing Center for Industrial Innovation (CIMATEC) for providing the necessary computational structure to perform the simulations; the Research Support Foundation of the State of Bahia (FAPESB) and the Coordination for the Improvement of Higher Education Personnel (CAPES) to partially finance the work.

\section{REFERENCES}

1 Oliveira, S. S. Análise do potencial eólico do estado da Paraíba utilizando modelos de mesoescala. Tese (Doutorado em Meteorologia) - Universidade Federal de Campina Grande, Centro de Tecnologia e Recursos Naturais, Campina Grande, 2013.

2 ABEEólica - Boletim anual de geração eólica. Disponível em: < http://www.abeeolica.org.br/wpcontent/uploads/2017/05/424_Boletim_Anual_de_Geracao_Eolica_2016_Alta.pdf>. Acesso em: 18 out 2017.

3 Surussavadee, C., 2017a. Evaluation of Tropical Near-Surface Wind Forecasts Using Ground Observations. The 8th International Renewable Energy Congress (IREC 2017).

${ }^{4}$ Skamarock, W. C., J. B. Klemp, J. Dudhia, D. O. Gill, D. M. Barker, M. G Duda, X.-Y. Huang, W. Wang, and J. G. Powers, 2008: A Description of the Advanced Research WRF Version 3. NCAR Tech. Note doi:10.5065/D68S4MVH

NCAR/TN-475+STR, 113

pp.

${ }^{5}$ Kumar, R. A., Dudhia, J., Bhowmik, S. K. R., 2010. Evaluation of physics options of the Weather Research and Forecasting (WRF) Model to simulate high impact heavy rainfall events over Indian Monsoon region. Geofisika, vol. 27, 101-125.

${ }^{6}$ Mohan, M., Bhati, S., 2011. Analysis of WRF Model Performance over Subtropical Region of Delhi, India. Advances in Meteorology, vol. 2011, pp. 1-13. doi:10.1155/2011/621235

7 Soni, M., Payra, S., Sinha, P., Verma, S., 2014. A Performance Evaluation of WRF Model Using Different Physical. Parameterization Scheme during Winter Season over a Semi-Arid Region, India. International Journal of Earth and Atmospheric Science, vol 1, pp. 104-114.

${ }^{8}$ Islam, T., Srivastava, P. K., Rico-Ramirez, M. A., Dai, Q., Gupta, M., Singh, S. K., 2015. Nat Hazards, vol. 76, pp. 1473-1495. doi: 10.1007/s11069-014-1494-8

${ }^{9}$ Imran, H. M., Kala, J., Ng, A. W. M., Muthukumaran, S., 2017. An evaluation of the performance of a WRF multi-physics ensemble for heatwave events over the city of Melbourne in the southeast Australia. Climate Dynamics, p. 1-34. doi: 10.1007/s00382-017-3758-y

${ }^{10}$ Hariprasad, K.B.R.R., Srinivas, C.V., Bagavath Singh, A., Vijaya Bhaskara Rao, S., Baskaran, R., Venkatraman, B., 2014. Numerical simulation and intercomparison of boundary layer structure with different PBL schemes in WRF using experimental observations at a tropical site. Atmospheric Research, v. 145-146, p. 27-44. DOI: http://dx.doi.org/10.1016/j.atmosres.2014. 03.023

${ }^{11}$ Carvalho, D., Rocha, A., Gómez-Gesteira, M., Santos, C.S., 2012. A sensitivity study of the WRF model in wind simulation for an area of high wind energy. Environmental Modelling \& Software, vol. 33, pp. 23-34. doi: 10.1016/j.envsoft.2012.01.019

12 Carvalho, D., Rocha, A., Gómez-Gesteira, M., Santos, C.S., 2014a. Sensitivity of the WRF model wind simulation and wind energy production estimates to planetary boundary layer parameterizations for onshore and offshore areas in the Iberian Peninsula. Applied Energy, vol. 135, pp. 234-246. doi: 10.1016/j.apenergy.2014.08.082

${ }^{13}$ Carvalho, D., Rocha, A., Gómez-Gesteira, M., Santos, C.S., 2014b. WRF Wind simulation and Wind energy production estimates forced by different reanalysis: Comparison with observed data for Portugal. Applied Energy, vol. 117, pp. 116-126. doi: 10.1016/j.apenergy.2013.12.001 
14 Giannakopoulou, E-M., Nhili, R., 2014. WRF Model Methodology for Offshore Wind Energy Applications. Advances in Meteorology, vol. 2014. doi: 10.1155/2014/319819

${ }^{15}$ Mattar, C., Borvarán, D., 2016. Offshore Wind power simulation by using WRF in the central coast of Chile. Renewable Energy, vol. 94, pp. 22-31. doi: 10.1016/j.renene.2016.03.005

16 Surussavadee, C., 2017a. Evaluation of Tropical Near-Surface Wind Forecasts Using Ground Observations. The 8th International Renewable Energy Congress (IREC 2017).

${ }^{17}$ Surussavadee, C., 2017b. Evaluation of WRF near-surface wind Simulations in Tropics Employing different planetary boundary layer schemes. The 8th International Renewable Energy Congress (IREC 2017).

18 Surussavadee, C., Aonchart, P. "Evaluation of WRF Physics Options for High-Resolution Weather Forecasting in Tropics Using Satellite Passive Millimeter-WaveObservations," Proc. IEEE Intern. Geosci. Remote Sens. Symp. 2013, Melbourne, Australia, pp. 2262 - 2265, Jul. 2013.

19 Jahn, D. E., Takle, E. S., Gallus Jr, W. A., 2017. Wind-Ramp-Forecast Sensitivity to Closure Parameters in a Boundary-Layer Parametrization Scheme. Boundary-Layer Meteorol, vol. 164, pp. 475-490. doi: 10.1007/s10546-017-0250-5

${ }^{20}$ Ramos, D. N. da S., Lyra, R. F. da F., Silva Jr., R. S. da, 2013. Previsão do vento utilizando o modelo atmosférico WRF para o estado de Alagoas. Revista Brasileira de Meteorologia, vol. 28, pp. 163-172.

${ }^{21}$ Atlas Eólico: Bahia. Camargo Schubert: Bahia, 2013.

22 Instituto Nacional de Meteorologia (INMET) Disponível em: https://clima.inmet.gov.br/GraficosClimatologicos/DF/83377.

${ }^{23}$ National Centers for Environmental Prediction/National Weather Service/NOAA/U.S. Department of Commerce. 2015, updated daily. NCEP GDAS/FNL 0.25 Degree Global Tropospheric Analyses and Forecast Grids. Research Data Archive at the National Center for Atmospheric Research, Computational and Information Systems Laboratory. https://doi.org/10.5065/D65Q4T4Z. Accessed 23 Jan 2017.

${ }^{24}$ Kitagawa, Y.K.L., Nascimento, E.G.S., Souza, N.B.P.de, Zucatelli, P.J., Aylas, G.Y.R., Moreira, D.M., Salvador, N., 2017. Assessment of the sensitivity of the WRF model using different PBL schemes over the Metropolitan Region of Salvador. XXXVIII Ibero-Latin American Congress on Computational Methods in Engineering (CILAMCE2017). doi: 10.20906/CPS/CILAMCE2017-0647

25 Janjic, Z. I., 1994. The step-mountain eta coordinate model: further developments of the convection, viscous sublayer, and turbulence closure schemes. Monthly Weather Review, vol. 122, pp. 927-945. doi: 10.1175/1520-0493(1994)122<0927:TSMECM>2.0.CO;2

${ }^{26}$ Cheng, W.Y.Y., Liu, Y., Zhang, Y., Mahoney, W.P., Warner, T.T., 2013. The impact of model physics on numerical wind forecasts. Renewable Energy, vol. 55, pp. 347-356. doi: 10.1016/j.renene.2012.12.041

${ }^{27}$ Zempila, M-M., Giannaros, T.M., Bais, A., Melas, D., 2016. Evaluation of WRF shortwave radiation parameterizations in predicting Global Horizontal Irradiance in Greece. Renewable Energy, vol. 86, pp. 831-840. doi: 10.1016/j.renene.2015.08.057

${ }^{28}$ Gunwani, P., Mohan, M., 2017. Sensitivity of WRF model estimates to various PBL parameterizations in different climatic zones over India. Atmospheric Research, vol. 194, pp. 43-65. doi: 10.1016/j.atmosres.2017.04.026 